\title{
ANALISIS KONDISI BANJIR DI KAMPUS USU BERBASIS HECRAS DAN GIS
}

\section{Fatimah Almadinah Siregar, Ahmad Perwira Mulia Tarigan, Muhammad Faisal}

Universitas Sumatera Utara, Indonesia

Email: fatimahalmadinah@gmail.com, a.perwira.mulia@gmail.com,mfaisal@usu.ac.id

\begin{tabular}{l}
\hline INFO ARTIKEL \\
\hline Diterima \\
25 Desember 2021 \\
Direvisi \\
05 Januari 2022 \\
Disetujui \\
15 Januari 2022 \\
\hline
\end{tabular}

Kata Kunci:

drainase; banjir; hecras; qgis

\begin{abstract}
ABSTRAK
Banjir merupakan salah satu bencana alam yang sering melanda berbagai daerah di Indonesia. Penelitian ini dilatarbelakangi oleh kondisi drainase di Kampus USU dengan luas lahan \pm 143 Ha terlihat tidak mampu menampung besarnya debit yang masuk baik disebabkan oleh daya tampung yang lebih kecil dari debit yang ada, kurangnya perawatan maupun sistem pengaliran dan pembuangan yang tidak sesuai lagi dengan lingkungan dan sebagainya. Studi ini bertujuan untuk mengetahui potensi genangan banjir di Kawasan Kampus USU dengan menghasilkan peta genangan banjir dari integrasi pemodelan antara software Hydrologic Engineering CenterRiver Analysis (HECRAS) dengan Geografic Information System (GIS). Dalam melakukan studi ini dilakukan pengumpulan data yang mencakup data topografi Kampus USU, data curah hujan dari BMKG, data tata guna lahan, data Topografi LIDAR. Metode Log Person III memenuhi syarat agihan distribusi frekensi curah hujan. Perhitungan debit banjir periodik menggunakan Metode Rasional untuk kala ulang banjir 1, 2, 5, 10, 20, 25, 50, dan 100 tahun. Dari hasil simulasi yang dilakukan terlihat daerah genangan yang terjadi di Kawasan Kampus USU. Beberapa lokasi banjir yang terjadi di Kampus USU adalah Jalan Universitas mulai dari depan Gelanggang Mahasiswa sampai persimpangan Jalan Dr. Mansur, Sepanjang Jalan Dr. Mansur, Fakultas Kesehatan Masyarakat, Fakultas Hukum.
\end{abstract}

\section{ABSTRACT}

Flood is one of the natural disasters that hit various regions in Indonesia. This research was motivated by the drainage conditions on the USU Campus with a land area of $\pm 143 \mathrm{Ha}$ which seemed unable to accommodate the amount of incoming discharge either due to a smaller capacity than the existing discharge, lack of maintenance and drainage and disposal systems that were no longer suitable for the environment and the environment. so. This study aims to determine the potential for flooding in the USU Campus Area by producing a flood evaluation map from modeling between the Hydrologic

How to cite:

E-ISSN:

Published by:
Siregar, F. A., Ahmad Perwira Mulia Tarigan, Muhammad Faisal (2022) Analisis Kondisi Banjir Di

Kampus USU Berbasis Hecras dan Gis, Jurnal Syntax Admiration 3(1). https://doi.org/10.46799/jsa.v3i1.383

$2722-5356$

Ridwan Institute 


Engineering Center-River Analysis (HECRAS) software and
the Geographic Information System (GIS). In conducting this
study, data were collected which included topographical data
on the USU Campus, rainfall data from the BMKG, land use
data, and LIDAR topographic data. The Log Person III method
meets the requirements for the distribution of rainfall
frequencies. Calculation of periodic flood discharge using the
Rational Method for flood return periods of 1, 2, 5, 10, 20, 25,
50, and 100 years. From the results of the simulation, it can be
seen in the area that occurred in the USU Campus Area.
Several locations of floods that occurred on the USU Campus
were University Street starting from the front of the Student
Center to the intersection of Jalan Dr. Mansur, Along Jalan
Dr. Mansur, Faculty of Public Health, Faculty of Law.
flood; hec-ras; qgis

\section{Pendahuluan}

Di Indonesia banjir merupakan salah satu bencana alam yang sering melanda berbagai daerah-daerah di dalam negeri, yang menimbulkan tak sedikit korban jiwa dan kerugian finansial, merusak fasilitas-fasilitas umum dan mengganggu aktivitas- aktivitas social-ekonomi yang dialami oleh para korban bencana. Kondisi iklim telah menyebabkan terjadinya fenomena hidrologi yang ekstrim seperti banjir yang menimbulkan kerugian material dan dampak yang signifikan terhadap lingkungan (Buta et al., 2017). Kondisi drainase di Kampus USU Medan di mana sebagian dari saluran yang ada di Kampus USU tidak berfungsi lagi sebagaimana mestinya, baik disebabkan oleh daya tampung yang lebih kecil dari debit yang ada, kurangnya perawatan maupun sistem pengaliran dan pembuangan yang tidak sesuai lagi (Mardiansyah, 2012). Selain itu terjadinya banjir dapat disebabkan oleh limpasan air permukaan (runoff) yang meluap dan volumenya melebihi kapasitas sistem drainase atau sistem aliran sungai.

Secara historis, upaya untuk mengurangi bahaya banjir dilakukan dengan membangun bendungan dan tanggul ataupun dengan mendesain bangunan anti banjir, namun cara ini dianggap tidak cukup dalam mengendalikan banjir (Stevens \& Hanschka, 2014). Bahaya dan kerugian banjir dapat dicegah dan diminimalisir dengan memberikan informasi yang akurat kepada masyarakat tentang risiko banjir melalui peta risiko banjir (Demir \& Kisi, 2016). Genangan yang sering ditemui di Kawasan perkotaan biasanya sering diartikan sebagai suatu kawsan dimana sistem drainasenya yang tidak cukup menampung kapasitas air yang ada atau tidak adanya saluran drainase dikawasan tersebut. Air yang akan terus tertahan di permukan tersebut kemudian menjadi kumpulan air yang dinamakan genangan (Bisri et al., 2012). Curah hujan dengan intensitas tinggi untuk waktu yang lebih singkat menghasilkan limpasan puncak yang tinggi dari daerah tangkapan perkotaan untuk lebih banyak lahan, dan pembangunan infrastruktur yang tidak terkendali, penggunaan lahan alami, tutupan lahan, dan jalur aliran telah mengakibatkan banjir (Rangari et al., 2019).

Luapan air dalam jumlah besar yang menggenangi suatu daerah dan menimbulkan kerusakan dan kerugian materi dan waktu. Seperti banyaknya banjir yang terjadi saat ini 
sangat merugikan masyarakat dan pemerintah, mulai dari jalanan yang terendam, air yang masuk ke rumah- rumah, sekolah, kampus, perkantoran, rumah sakit, serta tempat perbelanjaan. Menurut penelitian-penelitian yang telah dilakukan sebelumnya, Geographic Information System (GIS) telah berhasil digunakan dalam memvisualisasikan daerah genangan banjir dan menganalisis floodplain untuk menghasilkan peta estimasi kerusakan banjir dan peta risiko banjir.

Kota Medan sebagai salah satu kota metropolitan di Indonesia tidak terlepas dari masalah banjir. Banjir yang terjadi di Kota Medan kemungkinan diakibatkan oleh adanya perubahan tata guna lahan di daerah hulu kawasan Daerah Aliran Sungai (DAS), kesalahan dalam mengimplementasikan rencana tata ruang Kota Medan, maupun iklim ekstrim yang terjadi belakangan ini (Stevens \& Hanschka, 2014).

Salah satu wilayah yang berpotensi dilanda banjir di Kota Medan yaitu kawasan Universitas Sumatera Utara. Salah satu kampus yang berada di Jalan Dr. Mansyur ini mengalami genangan air yang cukup tinggi dan dalam waktu kurang lebih 1 jam untuk surut kembali ketika curah hujan cukup tinggi.

Sebagai salah satu langkah dalam mitigasi banjir, GIS dapat diterapkan untuk memetakan daerah risiko banjir dan mengestimasi kerugian yang diakibatkan banjir di DAS Babura, seperti yang telah dilakukan pada penelitian-penelitian sebelumnya.Undang-undang Nomor 24 Tahun 2007 Tentang Penanggulangan Bencana menyebutkan definisi banjir adalah peristiwa atau keadaan dimana terendamnya suatu daerah atau daratan karena volume air yang meningkat. Banjir adalah bencana alam yang paling sering terjadi dan paling banyak merugikan, baik dalam segi kemanusiaan maupun ekonomi. Menurut data dari Badan Nasional Penanggungan Bencana (BNPB), 90\% dari kejadian bencana alam di Indonesia berhubungan dengan banjir.Indonesia telah terjadi 385 peristiwa kejadian banjir mengakibatkan kerugian sebesar Rp.1646258337,- diantaranya 1047 jiwa korban luka - luka, 2853 unit rumah rusak berat, 1159 unit rumah rusak ringan, 7288 unit rumah ringan, 111443 unit rumah terendam banjir, 37 unit kerusakan fasilitas kesehatan, 211 unit kerusakan fasilitas peribadatan, dan 257 unit kerusakan fasilitas pendidikan (BNPB, 2019).

Menurut penelitian-penelitian yang telah dilakukan sebelumnya, Geographic Information System (GIS) telah berhasil digunakan dalam memvisualisasikan daerah genangan banjir dan menganalisis floodplain untuk menghasilkan peta estimasi kerusakan banjir dan peta risiko banjir. (Ahmad Shahiri Parsa.,et al 2016) melakukan penelitian "Floodplain Zoning Simulation by Using HEC - RAS and CCHE2D Models in the Sungai Maka River" dengan metode penilitian terdiri dari dua kategori data yaitu data spasial dan data atribut. data denah, data geometrik, data aliran, dan data desain hidraulik digunakan untuk pemodelan dengan model hec - ras.

GIS harus digunakan bersama-sama dengan model hidrolika untuk memperkirakan profil banjir dengan kala ulang tertentu (Demir \& Kisi, 2016). Salah satu model hidrolika yang paling populer adalah Hydrologic Engineering Centers River Analysis System (HEC - RAS) yang dikembangkan oleh United States Army Corps of 
Engineers (USACE). HEC - RAS merupakan software gratis dengan tampilan grafis yang dapat memudahkan penggunanya dalam studi banjir (Quirogaa et al., 2016).

Pada penelitian ini akan dilakukan Analisis Kondisi Banjir di Kampus USU Berbasis HEC - RAS dan GIS. Tujuan penelitian ini adalah menghasilkan peta genangan banjir di sekitar Kampus USU sebagai acuan untuk melihat daerah yang tergenang di sekitar kampus USU.

\section{Metode Penelitian}

\section{Lokasi Penelitian}

Universitas Sumatera Utara Batas-batas daerah perencanaan areal Kampus USU berada di kecamatan Medan Baru Kotamadya Medan. Areal Kampus USU Medan ini mempunyai batas- batas sebagai berikut:

- Sebelah Utara berbatasan dengan pemukiman penduduk sepanjang Jalan Sei Padang.

- Sebelah Timur berbatasan dengan pemukiman penduduk sepanjang Jalan Kapiten Pattimura.

- Sebelah Barat berbatassan dengan pemukiman penduduk sepanjang Jalan Pembangunan.

- Sebelah Selatan berbatasan dengan pemukiman penduduk sepanjang Jalan Berdikari.

- Luas total areal kampus USU adalah \pm 143 ha.

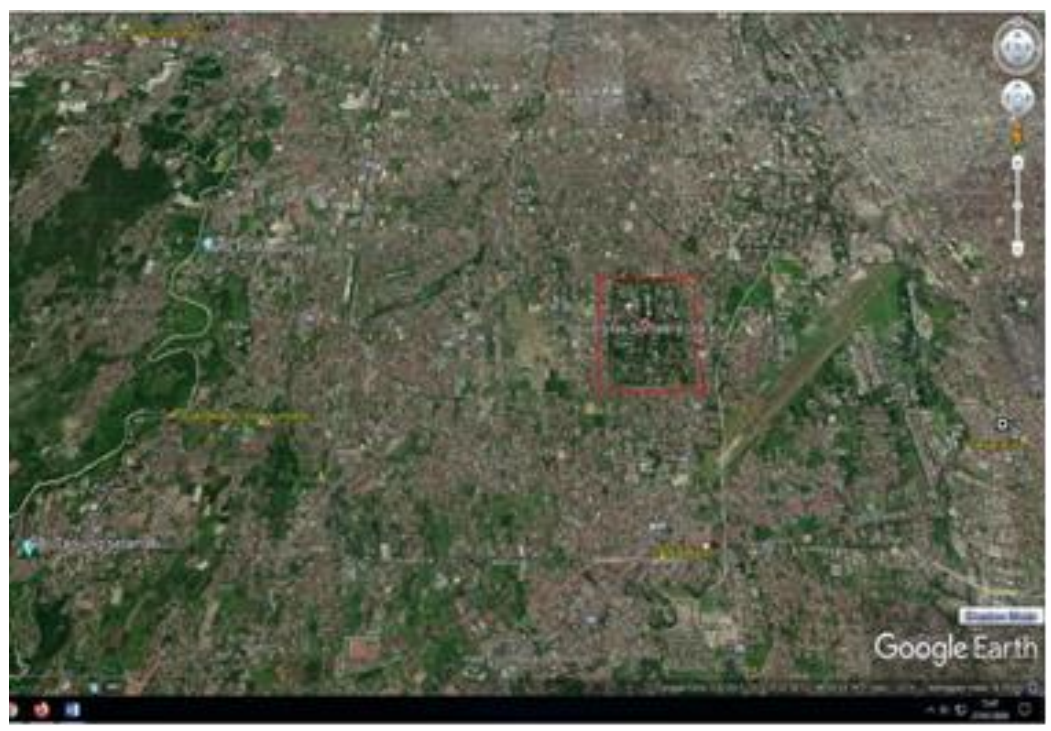

Gambar 1

Lokasi Penelitian Kampus USU

\section{Pengumpulan Dan Pengolahan Data}

Data sekunder yang digunakan yaitu data curah hujan dan peta stasiun penakar curah hujan dari Balai Wilayah Sungai I, Badan Meteorologi Klimatologi dan Geofisika (BMKG) Sampali, Peta topografi dan tata guna lahan dari Dinas 
Kehutanan Kota Medan, dan Peta DAS Babura dari Dinas Pengembangan Sumber Daya Air. Data mengenai Kampus USU yaitu Peta digital batas Daerah Aliran Saluran dan data keadaan drainase USU yang diperoleh dari USU tahun 2011. Serta data topografi LIDAR dari Konsultan Bappeda Kota Medan.

Data yang sudah dikumpulkan kemudian diolah dan di analisis dalam suatu perhitungan untuk mendapatkan hasil kesimpulan dari tujuan penelitian ini. Analisa Data Hidrologi dengan menghitung curah hujan rerata dengan menggunakan Metode Rata-rata Aljabar dan menghitung nilai intensitas hujan dengan menggunakan Persamaan Mononobe. Kemudian menghitung debit banjir maksimum dengan metode Rasional. Setelah itu debit yang diperoleh menjadi data yang diinput pada Steady Flow Data di simulasi Hecras.

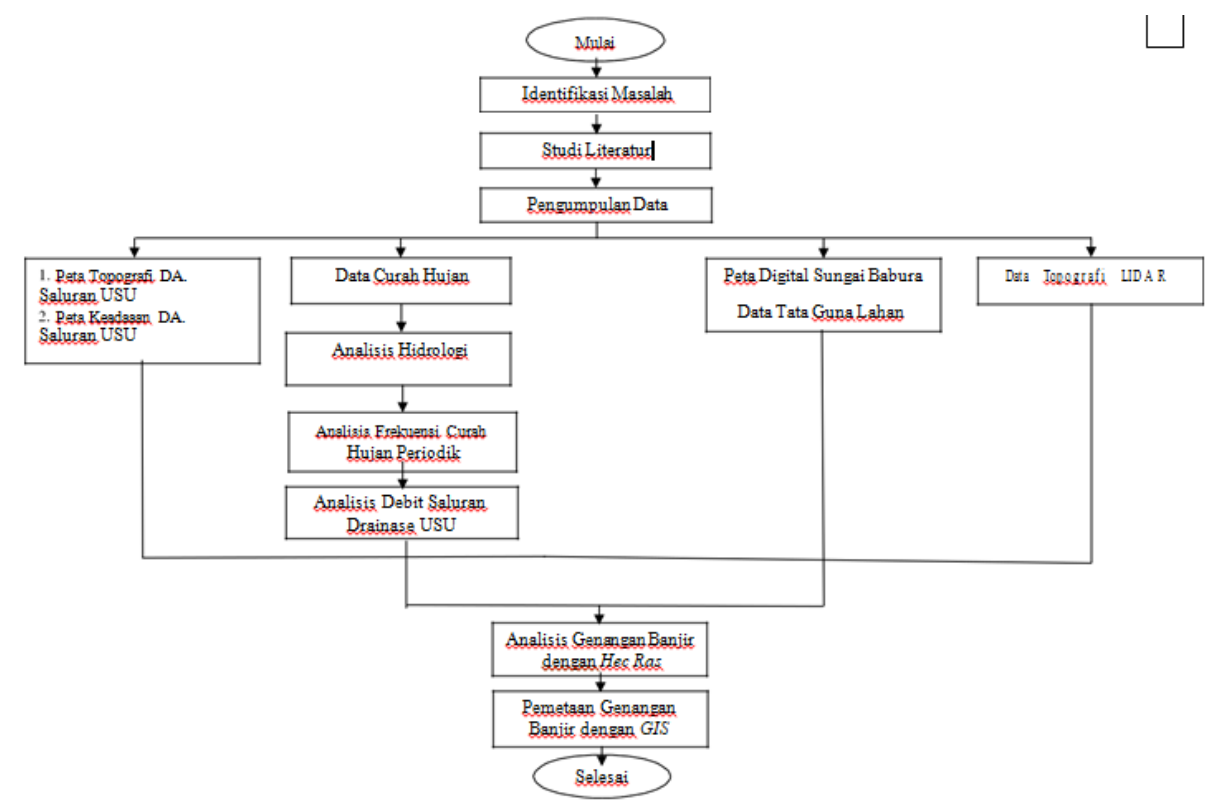

Gambar 2

Diagram alir penelitian

\section{Hasil dan Pembahasan}

\section{A. Analisis Hidrologi}

Analisis hidrologi yang dilakukan pada studi ini meliputi kegiatan mengolah data mentah sampai didapatkan harga debit limpasan (banjir). Data hujan yang dipakai untuk analisis ini berasal dari 3 (tiga) stasiun yang berada di wilayah kota Medan, yaitu: Sta. Tuntungan di koordinat (3,500244 LU ; 98,630518 BT), Sta. Sampali di koordinat $(3,5827930$ LU ; 98,583347 BT), dan Sta. Biru-biru di koordinat (3,5827930 LU ; 98,583347 BT).

Dikarenakan Kampus USU memiliki batas daerah aliran saluran sendiri maka untuk penggunaan Poligon Thiessen tersebut tidak digunakan, dalam hal ini yang digunakan adalah cara Rata-rata Aljabar karena USU memiliki luasan daerah yang kecil. Dan dari analisis ditunjukkan bahwa lokasi Kampus USU hanya berdekatan dengan Sta. Sampali. 


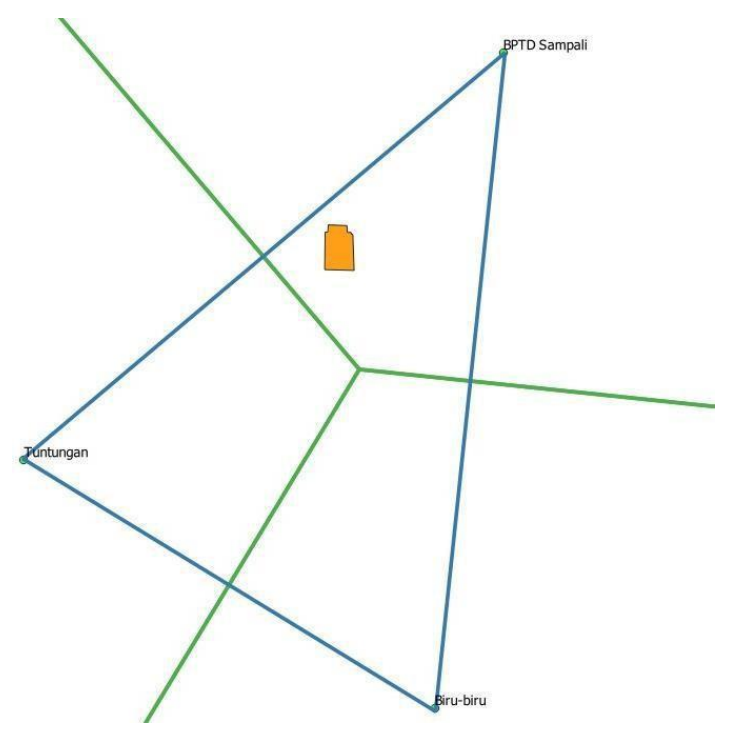

Gambar 3

Stasiun Curah Hujan

1) Analisis Frekuensi Curah Hujan

Tujuan dari analisis frekuensi curah hujan ini adalah untuk memperoleh curah hujan dengan beberapa perioda ulang. Dari pengolahan analisis data curah hujan di beberapa stasiun curah hujan berdasarkan curah hujan harian maksimum dari tahun 2010-2019, didapat ranking curah hujan regional yang terdapat dalam tabel dibawah ini.

Tabel 1

Perhitungan Rata-rata Aljabar Daerah Aliran Saluran Drainase USU

\begin{tabular}{cccccccccccccc}
\hline Tahun & Jan & Feb & Mar & Apr & Mei & Jun & Jul & Agt & Sept & Okt & Nov & Des & Maks \\
\hline 2010 & 71 & 48 & 401 & 24 & 20 & 47 & 69 & 48 & 40 & 41 & 66 & 80 & 401 \\
\hline 2011 & 78 & 35 & 64 & 64 & 39 & 40 & 54 & 98 & 59 & 58 & 63 & 60 & 98 \\
\hline 2012 & 40 & 50 & 42 & 57 & 83 & 65 & 65 & 46 & 60 & 75 & 60 & 33 & 83 \\
\hline 2013 & 29 & 66 & 53 & 63 & 27 & 39 & 58 & 33 & 32 & 70 & 21 & 111 & 111 \\
\hline 2014 & 20 & 22 & 35 & 31 & 46 & 49 & 34 & 91 & 66 & 41 & 57 & 165 & 165 \\
\hline 2015 & 42 & 46 & 10 & 12 & 39 & 11 & 86 & 50 & 52 & 76 & 90 & 43 & 90 \\
\hline 2016 & 23 & 71 & 9 & 9 & 40 & 41 & 49 & 54 & 84 & 47 & 57 & 34 & 84 \\
\hline 2017 & 37 & 6 & 40 & 44 & 22 & 64 & 32 & 82 & 34 & 84 & 65 & 135 & 135 \\
\hline 2018 & 29 & 40 & 18 & 68 & 35 & 42 & 62 & 33 & 56 & 147 & 76 & 106 & 147 \\
\hline 2019 & 27 & 20 & 9 & 46 & 159 & 21 & 31 & 65 & 102 & 70 & 50 & 54 & 159 \\
\hline Rata-rata & 39.6 & 40.4 & 68.1 & 41.8 & 51 & 41.9 & 54 & 60 & 58.5 & 70.9 & 60.5 & 82.1 & 82.1 \\
\hline
\end{tabular}

Pada analisis ini digunakan metoda analisis distribusi untuk memperkirakan curah hujan dengan tahun periode ulang tertentu. Metoda yang dipakai adalah metode yang ditentukan dengan melihat karakteristik distribusi hujan daerah 
setempat. Periode ulang yang akan dihitung pada masing-masing metode adalah untuk periode ulang 1,2, 5, 10, 20, 25, dan 100 tahun (ShahiriParsa et al., 2016).

Dari hasil perhitungan maka diperoleh kesimpulan bahwa untuk masingmasing stasiun yang ada, data yang memenuhi persyaratan sebagian besar adalah hasil metoda distribusi Log Pearson Tipe III. Untuk analisis selanjutnya dipilih hasil analisis frekuensi dari metode Log Pearson Tipe III. Untuk penentuan periode ulang yang digunakan, dilakukan sesuai standar untuk bangunan saluran sekunder menggunakan periode ulang 10 tahun. Dapat dilhat dalam Tabel berikut:

Tabel 2

Curah Hujan Harian Maksimum Metode Log Pearson Tipe III

\begin{tabular}{ccc}
\hline No. & $\begin{array}{c}\text { Kala Ulang } \\
\text { (tahun) }\end{array}$ & $\begin{array}{c}\text { Curah Hujan } \\
(\mathbf{m m})\end{array}$ \\
\hline 1. & 1 & 74.70 \\
\hline 2 & 2 & 115.13 \\
\hline 3 & 5 & 188.65 \\
\hline 4 & 10 & 261.25 \\
\hline 5 & 20 & 340.70 \\
\hline 6 & 25 & 386.14 \\
\hline 7 & 50 & 512.35 \\
\hline 8 & 100 & 674.86 \\
\hline Sumber: Analisis
\end{tabular}

Sumber: Analisis dan Pengolahan Data

2) Banjir Rencana Periode Ulang Tahunan

Adapun asumsi dari metode rasional adalah pengaliran maksimum terjadi kalau lama waktu curah hujan sama dengan lama waktu konsentrasi daerah alirannya. Untuk daerah yang luas pengalirannya lebih besar dari $80 \mathrm{Ha}$ maka maka digunakan persamaan rumus Rasional secara matematis dapat ditulis sebagai berikut:

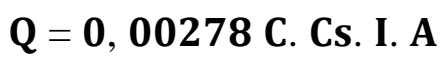

di mana: $\mathrm{Q}=$ debit dalam $\left(\mathrm{m}^{3} / \mathrm{det}\right), \mathrm{C}=$ koefisien pengaliran, $\mathrm{Cs}=$ koefisien tampungan, $\mathrm{I}=$ intensitas curah hujan $(\mathrm{mm} / \mathrm{jam}), \mathrm{A}=$ luas daerah pengaliran $\mathrm{Ha}$.

3) Koefisien Pengaliran (C)

Koefisien pengaliran merupakan nilai banding antara bagian hujan yang membetuk limpasan langsung dengan hujan total yang terjadi besaran ini dipengaruhi oleh tata guna lahan, kemiringan lahan, jenis dan kondisi tanah.

4) Koefisien Tampungan

Daerah yang memiliki cekungan untuk menampung air hujan relatif mengalirkan lebh sedikit air hujan dibandingkan dengan daerah yang tidak memiliki cekungan sama sekali. Efek tampungan oleh cekungan ini terhadap debit rencana diperkirakan dengan koefisien tampungan yang diperoleh dengan rumus sebagai berikut:

$$
\mathbf{C s}=2 \mathrm{~T}_{\mathbf{c}}
$$




$$
2 \mathbf{T}_{c}+\mathbf{T}_{\mathbf{d}}
$$

di mana: $\mathrm{Cs}=$ Koefisien tampungan, $\mathrm{Tc}=$ Waktu konsentrasi $(\mathrm{jam}), \mathrm{Td}=$ Waktu aliran air mengalir di dalam saluran dari hulu hingga ke tempat pengukuran (jam).

5) Waktu Konsentrasi

Waktu pengaliran (time of flow) tergantung pada perbandingan panjang saluran dan kecepatan aliran. Menurut rumus empiris dari Kirpich yang diasumsikan dari rumus Manning untuk koefisien kekasaran rata-rata dan jari-jari hidraulis.

6) Intensitas dan Lama Curah Hujan

Untuk Mencari Variabel I (Intensitas dan Lamanya Curah Hujan) dipakai rumus Mononobe. Rumus Mononobe sering digunakan di Jepang, untuk menghitung intensitas curah hujan setiap berdasarkan data curah hujan harian pada persamaan yaitu:

$$
I=\frac{R_{24}}{24}\left(\frac{24}{t_{c}}\right)^{2 / 3}
$$

di mana: $\mathrm{I}=$ intensitas curah hujan $(\mathrm{mm} / \mathrm{jam}), \mathrm{t}=$ lamanya curah hujan (menit), untuk rumus Mononobe dalam (jam), R24 = curah hujan yang mungkin terjadi berdasarkan masa ulang tertentu (curah hujan maximum dalam 24 jam $\mathrm{mm})$.

\section{B. Perhitungan Debit Sungai Babura}

Pemodelan genangan banjir selanjutnya memrlukanerlukan penambahan debit dari sungai Babura. Berikut ini adalah rekapitulasi perhitungan debit Sungai Babura.

Tabel 3

Rekapitulasi Debit Sungai Bubura Periode Ulang $1,2,5,10,20,25$, dan 100 Tahun

\begin{tabular}{lcccccccc}
\hline $\begin{array}{c}\text { Periode } \\
\text { Ulang }\end{array}$ & $\mathbf{1}$ & $\mathbf{2}$ & $\mathbf{5}$ & $\mathbf{1 0}$ & $\mathbf{2 0}$ & $\mathbf{2 5}$ & $\mathbf{5 0}$ & $\mathbf{1 0 0}$ \\
\hline Bekala & 96.29 & 126.29 & 139.16 & 155.86 & 161.53 & 164.44 & 170.23 & 175.57 \\
\hline Babura Hulu & 219.47 & 287.89 & 317.23 & 333.66 & 345.82 & 352.05 & 364.43 & 375.88 \\
\hline Babura & 128.06 & 164.57 & 182.41 & 193.03 & 201.24 & 205.46 & 214.13 & 222.43 \\
\hline
\end{tabular}

Tabel diatas menunjukkan hasil Rekapitulasi Debit Sungai Babura periode ulang 1, 2, 5, 10, 20, 25, dan 100 tahun yang selanjutnya digunakan sebagai input Steady Flow Data pada Hecras.

\section{Hasil Pemodelan Hecras}

Hasil pemodelan hecras Pemodelan yang dilakukan dalam menganalisis genangan banjir pada Saluran Drainase USU tersendiri ataupun menjadi satu kesatuan jaringan drainase saat menggunakan program HEC-RAS 5.0.7 yang perlu diperhatikan yaitu input data untuk HEC-RAS (Mardiansyah, 2012). Setiap data yang berhubungan dengan kondisi kajian sudah tentu merupakan input pada pemodelan. Program yang digunakan hanya menggunakan kejadian hidrologi dan kejadian 
hidraulika yang berpengaruh besar pada perhitungan. Pada penelitian yang dilakukan sebelumnya dilakukan hasil pemodelan untuk menggambarkan profil muka air pada jaringan drainase kampus Usu saja. Sedangkan pada penelitian ini dilakukan penambahan debit dari Sungai Babura yang dihubungkan menuju drainase Kampus Usu. Berikut ini merupakan hasil simulasi yang dilakukan. Beberapa lokasi banjir di Kampus USU adalah Jalan Universitas mulai dari depan Gelanggang Mahasiswa sampai persimpangan Jalan Dr. Mansur, Sepanjang Jalan Dr. Mansur, Fakultas Kesehatan Masyarakat, Fakultas Hukum.

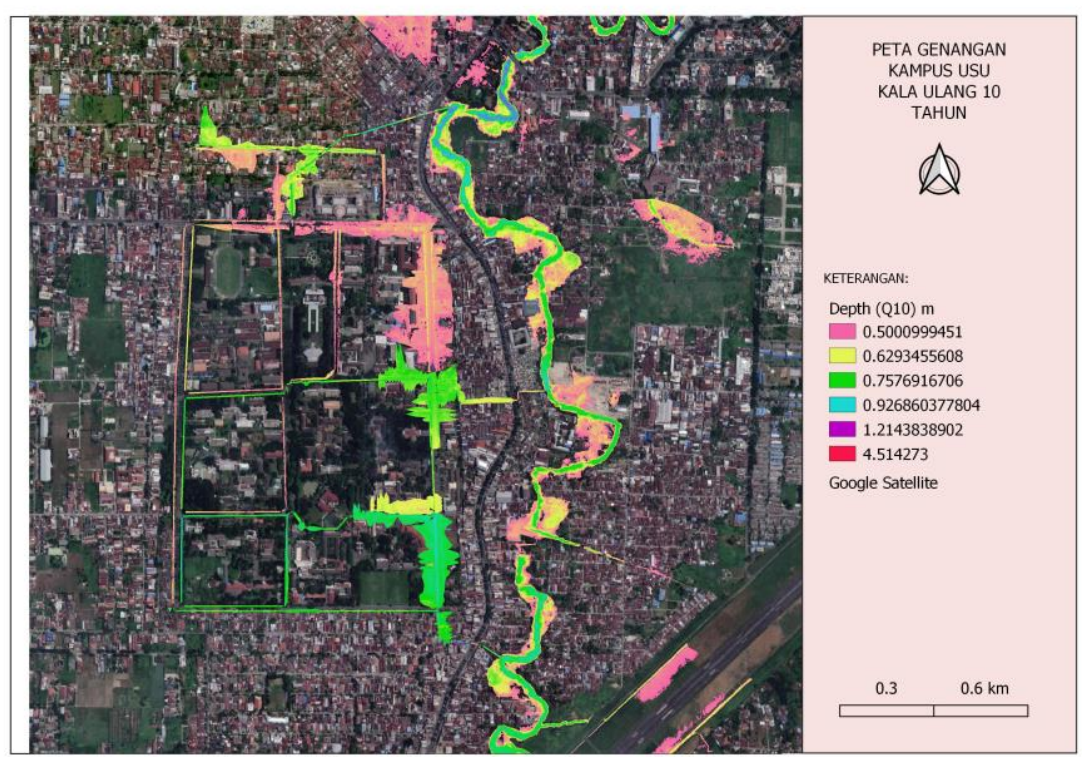

Gambar 3

Peta Genangan Kala Ulang 10 Tahun

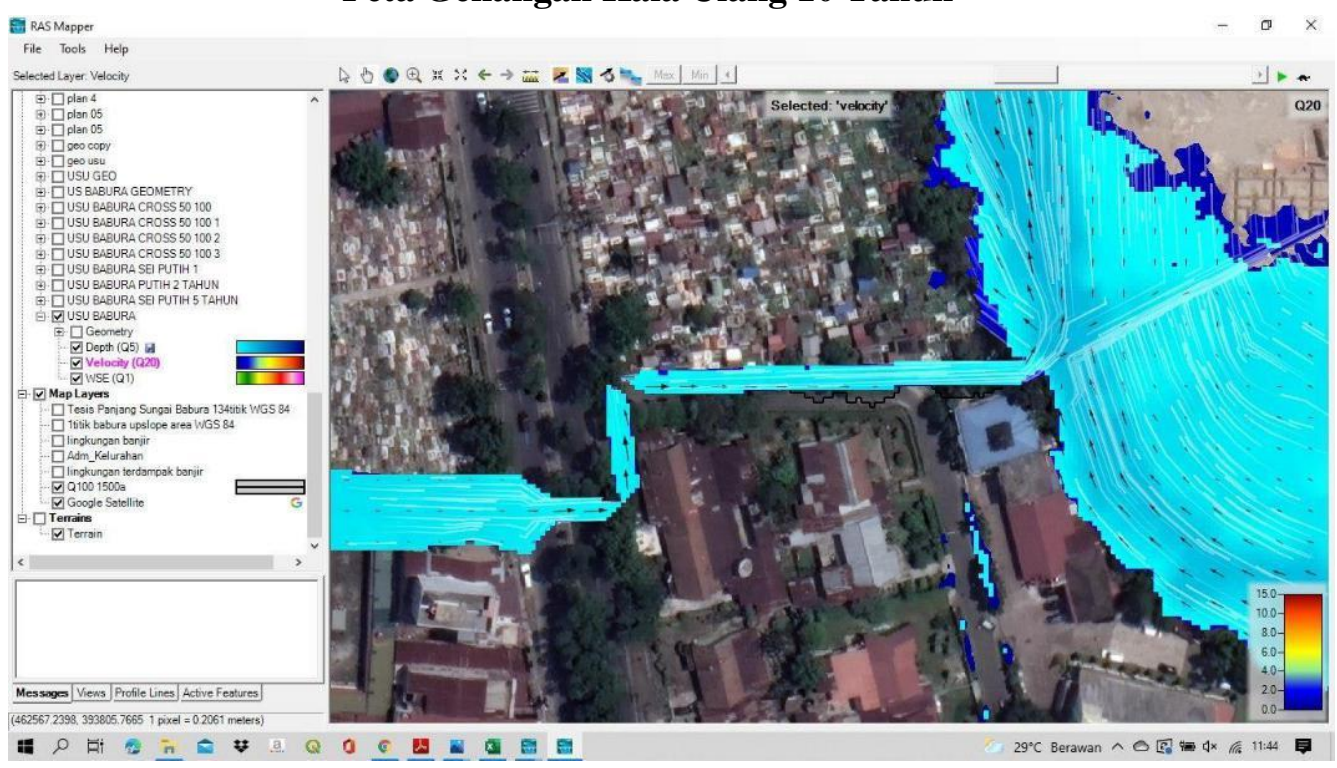

Gambar 4

Arah Aliran 


\section{Mitigasi}

Disebabkan oleh Intensitas Curah Hujan yang cukup tinggi menyebabkan limpasan permukaan yang cukup besar sehingga banjir dan genangan terjadi dibeberapa lokasi di Kawasan kampus USU. Untuk mengurangi dampak genangan yang terjadi maka perlu dilakukan upaya lain yang dapat dilakukan diantaranya adalah:

Alternatif bangunan resapan

- Kolam Retensi

Kolam retensi adalah kolam yang berfungsi untuk menampung air hujan sementara waktu dengan memberikan kesempatan untuk dapat meresap kedalam tanah yang operasionalnya dapat dikombinasikan dengan pompa atau pintu air. Konsep dasar dari kolam retensi adalah menampung volume air ketika debit tinggi kemudian secara perlahan mengalirkannya setelah debit kembali normal. Selain fungsi utamanya sebagai pengendali banjir, manfaat lain yang bisa diperoleh dari Kolam Retensi adalah sebagai konservasi air, karena mampu meningkatkan cadangan air tanah setempat.

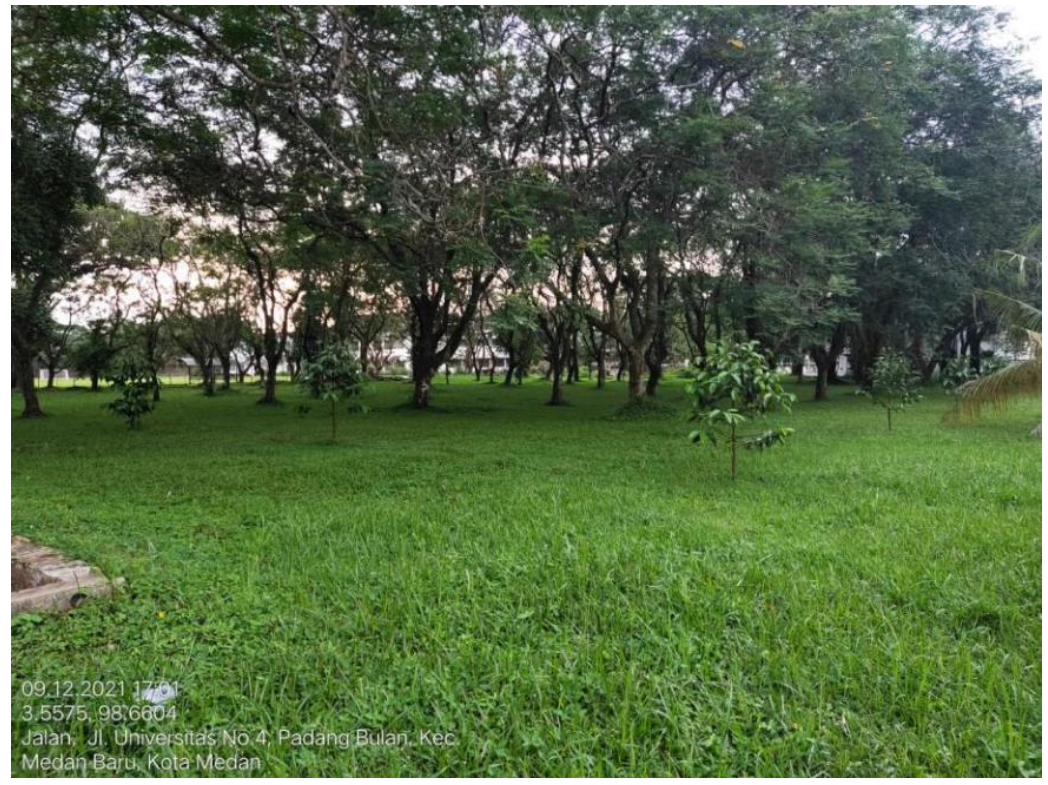

Gambar 5

Alternatif Lokasi Kolam Retensi

Salah satu lokasi yang dapat dijadikan tempat untuk kolam retensi adalah disamping Fakultas Hukum Pertemuan Jl. Dr. Sofyan dan Jl. Universitas Kampus USU. Lokasi ini menjadi salah satu lokasi yang memiliki ketersediaan lahan yang cukup baik dan tidak mengganggu sistem aliran drainase.

\section{Kesimpulan}

Dari hasil perhitungan pada Bab Analisa dan Pembahasan serta simulasi Softwere Hydologic Engineering Center River Analysis System (HEC-RAS) Versi 5.0.7 dapat disimpulkan bahwa: 1) Penyebab melimpahnya air hujan di beberapa tempat di Kampus 
USU adalah akibat kekurangan-mampuan beberapa saluran untuk mengalirkan air hujan karena kapasitasnya lebih kecil dari debit yang masuk. 2) Beberapa lokasi banjir di Kampus USU adalah Jalan Universitas mulai dari depan Gelanggang Mahasiswa sampai persimpangan Jalan Dr. Mansur, Sepanjang Jalan Dr. Mansur, Fakultas Kesehatan Masyarakat, Fakultas Hukum. 


\section{BIBLIOGRAFI}

Amin, M., Sarino, S., \& Haki, H. (2016). Perubahan Tutupan Lahan pada Daerah Aliran Sungai di Kota Palembang Berdasarkan Analisis Citra Landsat. Google Scholar

Bisri, M., Djakfar, L., \& Kusumadewi, D. A. (2012). Arahan Spasial Teknologi Drainase untuk Mereduksi Genangan di Sub Daerah Aliran Sungai Watu Bagian Hilir. Jurnal Teknik Perairan, 3(2), 260. Google Scholar

Buta, C., Mihai, G., \& Stănescu, M. (2017). Flash floods simulation in a small drainage basin using HEC-RAS hydraulic model. Ovidius University Annals, Series Civil Engineering, 19(1). Google Scholar

Demir, V., \& Kisi, O. (2016). Flood hazard mapping by using geographic information system and hydraulic model: Mert River, Samsun, Turkey. Advances in Meteorology, 2016. Google Scholar

Haki, H., \& Amin, M. (2016). Simulasi Profil Muka Air dan Potensi Genangan Banjir Ekstrim di Sungai Musi Menggunakan HEC-RAS dan SIG. Google Scholar

Hanie, M. Z., Tarigan, A. P. M., \& Khair, H. (2017). Analisis Mitigasi Banjir di Daerah Aliran Sungai Babura Berbasis Sistem Informasi Geografis (SIG). Jurnal Dampak, 14(1), 23-32. Google Scholar

Indrawan, I., \& Siregar, R. I. (2018). Pemodelan Penerapan Terowongan Air (Tunnel) dalam Mengatasi Banjir Akibat Luapan Sungai Deli. Jurnal Teknik Sipil ITB, 25(2), 113-120. Google Scholar

Lumi, M. (2015). Peringatan Dini Banjirkota Manado Berbasis Gis (Geographic Information System). Politeknik Negeri Manado. Google Scholar

Mardiansyah, Y. (2012). Evaluasi Sistem Drainase Kampus Universitas Sumatera Utara. Jurnal Teknik Sipil USU, 1(1). Google Scholar

Quirogaa, V. M., Kurea, S., Udoa, K., \& Manoa, A. (2016). Application of 2D numerical simulation for the analysis of the February 2014 Bolivian Amazonia flood: Application of the new HEC-RAS version 5. Ribagua, 3(1), 25-33. Google Scholar

Rangari, V. A., Sridhar, V., Umamahesh, N. V, \& Patel, A. K. (2019). Floodplain mapping and management of urban catchment using HEC-RAS: a case study of Hyderabad City. Journal of the Institution of Engineers (India): Series A, 100(1), 49-63. Google Scholar

Sari, A. I., Sudarsono, B., Sasmito, B., \& Harianto, H. (2013). Penentuan Area Luapan Kali Babon Akibat Kenaikan Debit Air Berbasis Sistem Informasi Geografis. Jurnal Geodesi Undip, 2(4). Google Scholar 
ShahiriParsa, A., Noori, M., Heydari, M., \& Rashidi, M. (2016). Floodplain zoning simulation by using HEC-RAS and CCHE2D models in the Sungai Maka river. Air, Soil and Water Research, 9, ASWR-S36089. Google Scholar

Sholi, I. N., Hadiani, R. R. R., \& Suryandari, E. S. (2020). Analisis Kapasitas Drainase Sebagai Upaya Pengendalian Banjir Di Kelurahan Sangkrah, Surakarta. Matriks Teknik Sipil, 8(2). Google Scholar

Stevens, M. R., \& Hanschka, S. (2014). Municipal flood hazard mapping: the case of British Columbia, Canada. Natural Hazards, 73(2), 907-932. Google Scholar

\section{Copyright holder:}

Fatimah Al Madinah Siregar, Ahmad Perwira Mulia, Muhammad Faisal (2022)

First publication right:

Jurnal Syntax Admiration

This article is licensed under:

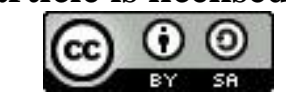

